\title{
Hepatocyte Growth Factor Is the Most Potent Endogenous Stimulant of Rabbit Gastric Epithelial Cell Proliferation and Migration in Primary Culture
}

\author{
Morio Takahashi, Shinichi Ota, Tadato Shimada, Eiji Hamada, Takao Kawabe, Takehito Okudaira, Masayuki Matsumura, ${ }^{\star}$ \\ Nobuyuki Kaneko, ${ }^{\ddagger}$ Akira Terano, ${ }^{5}$ Toshikazu Nakamura," and Masao Omata* \\ * Second Department of Internal Medicine, Faculty of Medicine, University of Tokyo, Tokyo 113, Japan; ${ }^{\ddagger}$ Department of Pathology, \\ Faculty of Medicine, University of Tokyo, Tokyo 113, Japan; ${ }^{8}$ Second Department of Medicine, School of Medicine, Dokkyo University, \\ Mibu, Tochigi 321-02, Japan; and "Biomedical Research Center, Osaka University Medical School, Osaka 565, Japan
}

\begin{abstract}
Various growth factors are suggested to be involved in gastric mucosal repair. Our previous studies have shown that exogenous hepatocyte growth factor (HGF) has a proliferative effect on gastric epithelial cells. In the present study, comparison of the maximum proliferative effects and the optimum concentrations of several growth factors revealed that HGF was the most potent mitogen for gastric epithelial cells, as is the case for hepatocytes. Restitution of gastric epithelial cell monolayers was assessed using a round wound restitution model. HGF was the most effective agent for facilitating gastric epithelial restitution among those tested. A binding assay revealed specific binding of HGF to its receptor on gastric epithelial cells. Northern blot analysis confirmed the expression of specific HGF receptor mRNA (c-met) by gastric epithelial cells but not by gastric fibroblasts. To investigate endogenous HGF production, we determined the effect of gastric fibroblast-conditioned medium on epithelial proliferation and restitution. The conditioned medium produced similar effects to HGF and its activity was neutralized by an anti-HGF antibody. In addition, expression of HGF mRNA was detected in gastric fibroblasts but not in gastric epithelial cells. Our immunohistochemical study confirmed these in vitro data by means of demonstrating the existence and localization of HGF at human native gastric mucosa. HGF was localized at fibroblasts under the epithelial cell layer around gastric ulcers. These results suggest that HGF may be a potent endogenous promotor of gastric epithelial cell proliferation and migration, and may contribute to gastric mucosal repair through a paracrine mechanism. (J. Clin. Invest. 1995. 95:1994-2003.) Key words: hepatocyte growth factor - gastric epithelial cell • proliferation • restitution - Northern blot hybridization
\end{abstract}

\section{Introduction}

The epithelial lining of the stomach is rapidly renewed by the proliferation of immature gastric epithelial cells. These cells are

Address correspondence to Morio Takahashi, M.D., 2nd Department of Internal Medicine, Faculty of Medicine, University of Tokyo 7-3-1 Hongo, Bunkyo-ku, Tokyo 113, Japan. Phone: 03-3815-5411 ext. 3070; Fax: 03-3814-0021.

Received for publication 5 May 1994 and in revised form 19 December 1994.

J. Clin. Invest.

(C) The American Society for Clinical Investigation, Inc.

0021-9738/95/05/1994/10 \$2.00

Volume 95, May 1995, 1994-2003 located in the proliferating zone of the gastric glands (1) and are regulated by various autocrine, paracrine, and hormonal factors. The proliferative response of these cells to growth factors might be important in maintaining gastric mucosal integrity and in accelerating peptic ulcer healing. Several growth factors, including epidermal growth factor (EGF), transforming growth factor- $\alpha$ (TGF- $\alpha$ ), insulin, and insulin-like growth factor 1 , have been reported to induce a mitogenic response of normal gastric epithelial cells in primary culture (2-5). Among these factors, the expression of TGF- $\alpha$ has been reported to increase after gastric injury (6) and it is produced by gastric epithelial cells (7). In addition, Folkmann et al. have suggested that basic fibroblast growth factor (bFGF), a potent growth promoter for vascular endothelial cells, might be important in duodenal ulcer repair $(8,9)$. They also reported that exogenously administered bFGF accelerated duodenal ulcer healing to the same extent as a histamine $\mathrm{H}_{2}$ receptor antagonist (10). These findings have suggested the importance of growth factors in the maintenance and repair of the gastric mucosa, although the role of each individual factor requires further investigation.

In addition to proliferation, previous reports have suggested that cell migration is an essential part of the early process of gastric mucosal repair (11). After various forms of gastric injury, mucosal integrity is re-established by the rapid migration of epithelial cells across the wound margins in a process termed restitution. Stress ulcers of the gastric mucosa heal rapidly in rats and are almost completely repaired within $24 \mathrm{~h}$ (12). The rapid process of mucosal restitution involves sloughing of the damaged epithelial cells, while viable cells migrate from adjacent to, or just beneath, the injured surface to cover the denuded area $(13,14)$. Early mucosal restitution appears to be an initial response which prevents deeper mucosal damage and occurs too rapidly to be accounted for by cell proliferation (15). The lost cells are subsequently replaced by proliferation, which is thought to begin $12-16 \mathrm{~h}$ after injury and continues for 1-2 d (16). Therefore, both the migratory and the mitogenic responses of epithelial cells to various growth factors might be important in maintaining gastric mucosal integrity and accelerating peptic ulcer healing. It is of interest that growth factors such as EGF, TGF- $\alpha$, and insulin have been shown to promote the migration of gastric epithelial cells.

Hepatocyte growth factor (HGF) ${ }^{1}$ is a hepatotrophic factor promoting liver regeneration that was initially purified from rat platelets $(17,18)$. HGF has been shown to stimulate the growth of various epithelial cells, such as renal tubular cells (19), epidermal melanocytes (20), and keratinocytes (21), sug-

1. Abbreviations used in this paper: BME, basal Eagle's medium; HGF, hepatocyte growth factor; RT-PCR, reverse transcription polymerase chain reaction. 
gesting that it might play an important role in the repair of these tissues. This factor is produced by mesenchymal cells, including fibroblasts, Kupffer cells, and endothelial cells, but not by epithelial cells $(22,23)$. However, the role of HGF in the gastric mucosa has not been well studied, despite the fact that gastric epithelial cells express c-met protein (24), the HGF receptor.

We have previously shown that HGF induces the proliferation of rabbit gastric epithelial cells in primary culture (25) and that the conditioned medium of gastric fibroblasts also induces gastric epithelial cell proliferation. However, the proliferative factor in the conditioned medium was not determined in that study. In the present study, we confirmed that the factor was HGF by demonstrating the expression of HGF mRNA and by a neutralizing experiment using anti-HGF antibody. We also characterized the effect of HGF on the migration of gastric epithelial cells using an in vitro restitution model. To confirm these in vitro data, we performed immunohistochemical study, using human gastric biopsy samples. Our findings suggest the importance of HGF as a paracrine factor with a key role in the mesenchymal-epithelial interactions of the gastric mucosa. Although there have been numerous studies indicating that HGF functions in a paracrine fashion, it has never been clearly demonstrated that HGF derived from a particular tissue acts on epithelial cells of the same tissue. Therefore, this is the first actual demonstration that locally produced HGF stimulates the proliferation and migration of epithelial cells via a paracrine mechanism.

\section{Methods}

\section{Animals}

Japanese white rabbits of both sexes (Doken Laboratory, Ibaraki) weighing $2.5-3.0 \mathrm{~kg}$ were used.

\section{Reagents}

Human EGF was purchased from Wakunaga (Hiroshima, Japan) and human insulin was obtained from Shionogi (Osaka, Japan). Human recombinant HGF was purified from the conditioned medium of $\mathrm{CHO}$ cells transfected with an expression vector containing the complete human HGF cDNA (26). An anti-rabbit HGF antibody was kindly provided by Dr. Reza Zarnegar (University of Pittsburgh, Pittsburgh, PA) (27). The reagents for gastric epithelial cell isolation and culture were as follows: Coon's modified Ham's F-12 medium (KC Biological Inc., Lenexa, KS), basal Eagle's medium (BME), minimal essential medium (MEM; Sigma Chemical Co., St. Louis, MO), $\mathbf{N}$-2-hydroxyethylpiperazine- $\mathrm{N}$-2-ethanesulfonic acid (Hepes) buffer (Sigma Chemical Co.), bovine serum albumin (BSA) (fraction V; Sigma Chemical Co.), Hanks' balanced salt solution (HBSS; GIBCO BRL, Gaithersburg, MD), crude type I collagenase (Sigma Chemical Co.), and ethylenediaminetetraacetic acid (EDTA, Sigma Chemical Co.). $\left[{ }^{3} \mathrm{H}\right]$ Thymidine was purchased from New England Nuclear (Boston, MA), a QuickPrep mRNA purification kit was purchased from Pharmacia Biotech (Uppsala, Sweden ), a Megaprime DNA labeling kit was obtained from Amersham (Buckinghamshire, England), and Hybond-N+ was also obtained from Amersham. A Quiaex DNA gel extraction kit was purchased from Quiagen (Chatsworth, CA)

\section{Cell culture}

Gastric fundic mucosal cells were isolated from adult rabbits and cultured as described previously (28). In brief, the fundic mucosa was quickly separated from rabbit stomachs, scraped bluntly, and minced into 2-3- $\mathrm{mm}^{2}$ pieces, which were incubated in BME containing crude type I collagenase $(0.35 \mathrm{mg} / \mathrm{ml})$. This was followed by incubation in BME containing $1 \mathrm{mM}$ EDTA and further incubation in the former solution, which was performed twice serially at $37^{\circ} \mathrm{C}$ and $\mathrm{pH} 7.4$ in an atmosphere of $5 \% \mathrm{CO}_{2}$ and $95 \% \mathrm{O}_{2}$. Cells from the final incubation were washed in $\mathrm{HBSS}$ and cultured at $37^{\circ} \mathrm{C}$ in a moist atmosphere containing $5 \% \mathrm{CO}_{2}$. The culture medium was $\mathrm{F}-12$ medium supplemented with $10 \%$ heat inactivated $\left(56^{\circ} \mathrm{C}\right.$ for $\left.30 \mathrm{~min}\right)$ fetal bovine serum (GIBCO BRL), $15 \mathrm{mM}$ Hepes buffer, $100 \mathrm{U} / \mathrm{ml}$ penicillin, $100 \mathrm{U} / \mathrm{ml}$ streptomycin, and $5 \mu \mathrm{g} / \mathrm{ml}$ fungizone.

Gastric fundic fibroblasts were also obtained as described above by continuing the culture for $>1 \mathrm{mo}$, after which the mucosal epithelial cells died and fibroblasts became predominant. During culture, F-12 medium with $10 \%$ FBS was changed twice a week. Fibroblast-conditioned medium was obtained from these cultures after the fibroblasts became predominant. To produce the conditioned medium, fibroblasts were incubated for $24 \mathrm{~h}$ at $37^{\circ} \mathrm{C}$ in $\mathrm{F}-12$ medium with $0.1 \%$ BSA.

\section{Cell characterization}

After culture for $48 \mathrm{~h}$, cells were examined morphologically, histochemically, and electron microscopically as described elsewhere $(28,29)$. In brief, cultures were first examined with a phase-contrast microscope. To distinguish parietal cells, succinic dehydrogenase activity was determined by the method of Nachlas et al. (30). Bowie staining (31) was used to detect chief cells and periodic acid Schiff (PAS) staining was employed to identify mucous cells. To distinguish mesenchymal cells from epithelial cells, an anti-vimentin antibody and an anti-cytokeratin antibody were employed to stain vimentin and cytokeratin, respectively.

\section{Assessment of cell proliferation}

The effects of various growth factors on DNA synthesis were determined by the $\left[{ }^{3} \mathrm{H}\right]$ thymidine incorporation method. Isolated cells were inoculated onto 24-well culture plates (Primaria, Falcon Labware) at a density of $1.4 \times 10^{5}$ cells/well, and then cultured for $24 \mathrm{~h}$ in F-12 medium supplemented with $10 \%$ FBS. After culture for a further $24 \mathrm{~h}$ in serumfree F-12 medium, culture was performed in serum-free F-12 medium supplemented with the test agents (EGF, insulin, HGF, or gastric fibroblast-conditioned medium), $0.1 \%$ BSA, and $\left[{ }^{3} \mathrm{H}\right]$ thymidine (final concentration: $1.0 \mu \mathrm{Ci} / \mathrm{ml}$ ). $24 \mathrm{~h}$ later, the cells were washed and $5 \%$ trichloroacetic acid was added. Then the cells were let stand for $1 \mathrm{~h}$ at $4^{\circ} \mathrm{C}$, solubilized in $1 \mathrm{~N} \mathrm{NaOH}$, and neutralized with $\mathrm{HCl}$. The solution was placed in a Readycap with XtalScint solvent-free scintillation medium (Beckman Instruments, Inc., Fullerton, CA) and air-dried overnight, after which the radioactivity was counted using a liquid scintillation counter. To allow accurate comparison of the effect of each agent on cell growth, all studies were done precisely at the same time using cells from a single rabbit stomach.

\section{Restitution model}

The effect of HGF and some other growth factors was studied using an in vitro model of gastric epithelial restitution. Confluent monolayers of primary cultured gastric epithelial cells in 24-well culture plates were wounded with a custom-made scraper that produced a round wound with a diameter of $\sim 1.5 \mathrm{~mm}$ in each well. Then the monolayers were washed with fresh serum-free medium, and were further cultured in fresh serum-free medium in the presence or absence of growth factors including HGF, EGF, 10\% FBS, and fibroblast-conditioned medium. Restitution of the epithelial cells was assessed in a blind fashion to avoid observer bias. Accordingly, determination of the uncovered area was performed by a person who was unaware of the details of the experiment. Photomicrographs of the wounds were obtained at a 40fold magnification using a Nikon microscope and camera. Then prints were made and wound area was cut out from each print and weighed. The weight was precisely related to the area, since the thickness of the prints was constant. Experiments were performed six times and the results were expressed as the mean $\pm \mathrm{SE}$. Morphological observation was also performed at a stronger magnification.

\section{Binding assay}

The binding assay was carried out at $10^{\circ} \mathrm{C}$ by incubating ${ }^{125} \mathrm{I}$-HGF with a monolayer of gastric epithelial cells as described elsewhere (32). Gastric epithelial cells in primary culture were incubated for $48 \mathrm{~h}$, after 
which the monolayer was washed with the binding buffer $(20 \mathrm{mM}$ Hepes and $0.2 \% \mathrm{BSA} /$ Hanks, $\mathrm{pH} 7.0$ ) and pre-incubated with the same buffer for $30 \mathrm{~min}$ at $10^{\circ} \mathrm{C}$. After equilibration, fresh ice-cold binding buffer containing various concentrations of ${ }^{125}$ I-HGF with or without an excess of unlabeled HGF was added as indicated. Incubation was done for $1 \mathrm{~h}$ at $10^{\circ} \mathrm{C}$ and halted by aspiration of the medium. The monolayer was washed 3-5 times with ice-cold buffer and the radioactivity bound to the cells was measured in a gamma-counter after solubilizing the monolayer with $1 \mathrm{~N} \mathrm{NaOH}$. We performed Scatchard analysis, plotting bound ${ }^{125} \mathrm{I}-\mathrm{HGF} /$ free ${ }^{125} \mathrm{I}-\mathrm{HGF}$ as vertical axis and bound ${ }^{125} \mathrm{I}-$ HGF as horizontal axis (32). In order to obtain regression, we used the least squares method. All binding experiments were done in triplicate.

\section{Neutralization experiment}

Fibroblast-conditioned medium was incubated with chicken anti-rabbit HGF antibody or chicken IgG for $2 \mathrm{~h}$ at $37^{\circ} \mathrm{C}$ and its effect on gastric epithelial cell proliferation was determined by the $\left[{ }^{3} \mathrm{H}\right]$ thymidine incorporation assay described above. F-12 medium with EGF was also incubated with the anti-rabbit HGF antibody and its effect on gastric epithelial cells was assessed to determine the specificity of the antibody.

Reverse transcription polymerase chain reaction for $c$-met Total cellular RNA was isolated from cultured cells grown to confluence in 100-mm culture plates using RNAzol ${ }^{\mathrm{TM}} \mathrm{B}$ (Cinna/Biotecx Laboratories, Inc, Houston, Texas). $5 \mu \mathrm{g}$ total RNA was reverse transcribed using M-MLV reverse transcriptase (GIBCO BRL), after which the product was denatured at $95^{\circ} \mathrm{C}$ for $5 \mathrm{~min}$ and cooled on ice. The polymerase chain reaction (PCR) was carried out in a final volume of $50 \mu \mathrm{l}$ reaction buffer containing $50 \mathrm{mM} \mathrm{KCl}, 10 \mathrm{mM}$ Tris (pH 8.3), $1.5 \mathrm{mM}$ $\mathrm{MgCl}_{2}, 0.001 \%$ gelatin, $200 \mu \mathrm{M}$ each of dATP, dGTP, dCTP, and dTTP, and $2.5 \mathrm{U}$ of Taq polymerase (Promega Corp., Madison, WI). Using $10 \mu \mathrm{l}$ of the reverse transcription product, 30 cycles of amplification of the c-met first-strand cDNA were performed with $30 \mathrm{pmol}$ of each met primer (sense: $5^{\prime}{ }^{3905}$ GGT TGC TGA TTT TGG TCA TGC ${ }^{3925} 3^{\prime}$; antisense: $5^{\prime}{ }^{4126}$ TTC GGG TTG TAG GAG TCT TCT ${ }^{4146} 3^{\prime}$ ). Each amplification cycle consisted of denaturation at $93^{\circ} \mathrm{C}$ for $30 \mathrm{~s}$, annealing at $53.1^{\circ} \mathrm{C}$ for $45 \mathrm{~s}$, and polymerization at $72^{\circ} \mathrm{C}$ for $45 \mathrm{~s}$. PCR products $(10 \mu \mathrm{l})$ were electrophoretically separated on $2 \%$ agarose gel in $1 \times$ TAE buffer, after which the gel was stained with ethidium bromide $(0.5$ $\mu \mathrm{g} / \mathrm{ml})$.

\section{Northern blot hybridization}

Total RNA was extracted from cultured gastric epithelial cells or gastric fibroblasts by the AGPC method (33) and purified to mRNA on an oligo(dT)-Cellulose Spun Column using a QuickPrep mRNA purification kit. Two micrograms of poly (A) + RNA was electrophoresed on $1 \%$ agarose gel containing $0.66 \mathrm{M}$ formaldehyde and transferred to a HYbond-N+ nylon membrane filter. As a probe for HGF mRNA, a 1.4 kb HGF cDNA fragment including the 3 '-portion of the $\alpha$ subunit, the $\beta$ subunit, and part of the 3 '-untranslated region was obtained from pRBCl using the restriction enzyme EcoRI (34). As a probe for the detection of c-met, the PCR product obtained as described above was purified with a Quiaex DNA gel extraction kit. The cDNA was labeled with $\left[\alpha{ }^{32} \mathrm{P}\right] \mathrm{dCTP}$ by the random primer method using a Megaprime DNA labeling system, after which the membrane was hybridized with the cDNA probe at $65^{\circ} \mathrm{C}$ for $2 \mathrm{~h}$ in rapid hybridization buffer. Then the membrane was washed in $2 \times$ SSC with $0.1 \%$ SDS for $20 \mathrm{~min}$ at room temperature, followed by washing twice in $0.1 \times$ SSC with $0.1 \%$ SDS for $15 \mathrm{~min}$ at $65^{\circ} \mathrm{C}$. Finally, it was exposed to $\mathrm{x}$-ray film for $48 \mathrm{~h}$ at $-70^{\circ} \mathrm{C}$ using an intensifying screen.

\section{Reverse transcription polymerase chain reaction for $H G F$}

Biopsy specimens were obtained endoscopically from the edges of gastric ulcers and from normal mucosa and were immediately frozen in liquid nitrogen. Later, total cellular RNA was isolated, using RNA$\mathrm{zol}^{\mathrm{TM} B}$ (Cinna/Biotecx Laboratories, Inc, Houston, TX). $5 \mu \mathrm{g}$ total RNA was reverse transcribed using M-MLV reverse transcriptase (GIBCO BRL). The product was heated at $95^{\circ} \mathrm{C}$ for $5 \mathrm{~min}$ and then
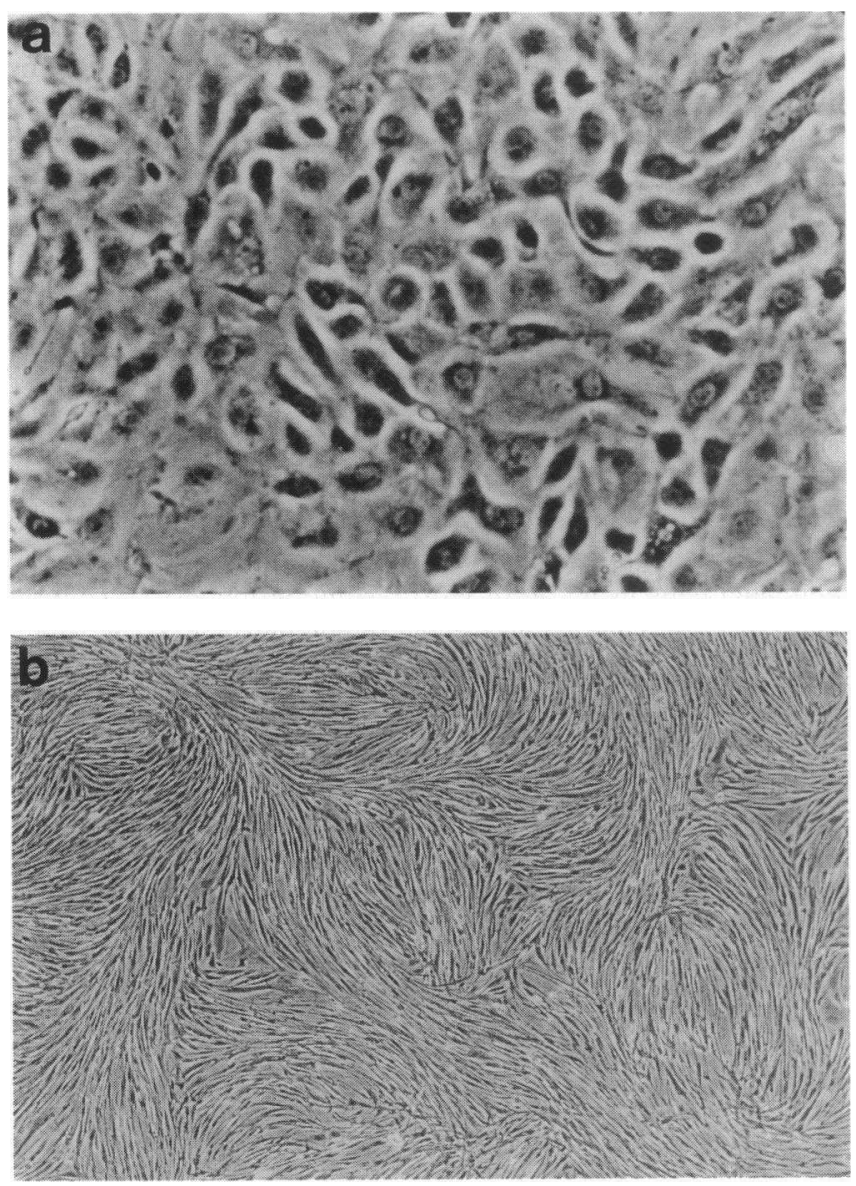

Figure 1. (a) Phase-contrast micrograph of rabbit gastric epithelial cells in primary culture $(\times 100)$. $(b)$ Phase-contrast micrograph of rabbit gastric fibroblasts in primary culture $(\times 40)$.

cooled on ice. The PCR was carried out in the same buffer as that used for the c-met PCR. Using $10 \mathrm{ml}$ of the reverse-transcribed product, 40 cycles of amplification were performed for the first-strand hHGF cDNA. 30 pmoles of each of the hHGF primers was used (sense: 5 '-CAG CGT TGG GAT TCT CAG TAT-3'; ; antisense: CCT ATG TTT GTT CGT GTT GGA-3').

These primers respectively represent the sense sequence in the K3 (exon 8) domain of the $\alpha$ chain (nucleotide 979-1000) and the antisense sequence in the $5^{\prime}$ portion (exon 13) of the $\beta$ chain (nucleotide 1497-1518) of hHGF mRNA (17). Each amplification cycle consisted of $90 \mathrm{~s}$ of denaturation at $94^{\circ} \mathrm{C}, 1 \mathrm{~min}$ of annealing at $57^{\circ} \mathrm{C}$, and $2 \mathrm{~min}$ of polymerization at $72^{\circ} \mathrm{C} .10 \mu \mathrm{l}$ of each PCR product was electrophoretically separated on $2 \%$ agarose gel in $1 \times$ TAE buffer. The gel was then stained with $0.5 \mu \mathrm{g} / \mathrm{ml}$ ethidium bromide and was visualized under ultraviolet light (35).

\section{HGF immunohistochemistry}

Anti-serum. A polyclonal antiserum was raised in rabbits against recombinant human HGF purified from the culture fluid of transformed $\mathrm{CHO}$ cells. The anti-serum reacted with h-rHGF and recognized to both the $\alpha$ - and $\beta$-chains, but did not react with rat or rabbit HGF (data not shown).

Immunohistochemistry. Biopsy specimens were obtained endoscopically from the edges of gastric ulcers or from normal mucosa at the University of Tokyo Hospital (Tokyo, Japan). Written informed consent was obtained from all patients. Specimens were processed by the modified AMeX method (36). In brief, the tissues were first fixed in acetone at $4^{\circ} \mathrm{C}$ for $20 \mathrm{~min}$ and then at $-20^{\circ} \mathrm{C}$ overnight, dehydrated in acetone 

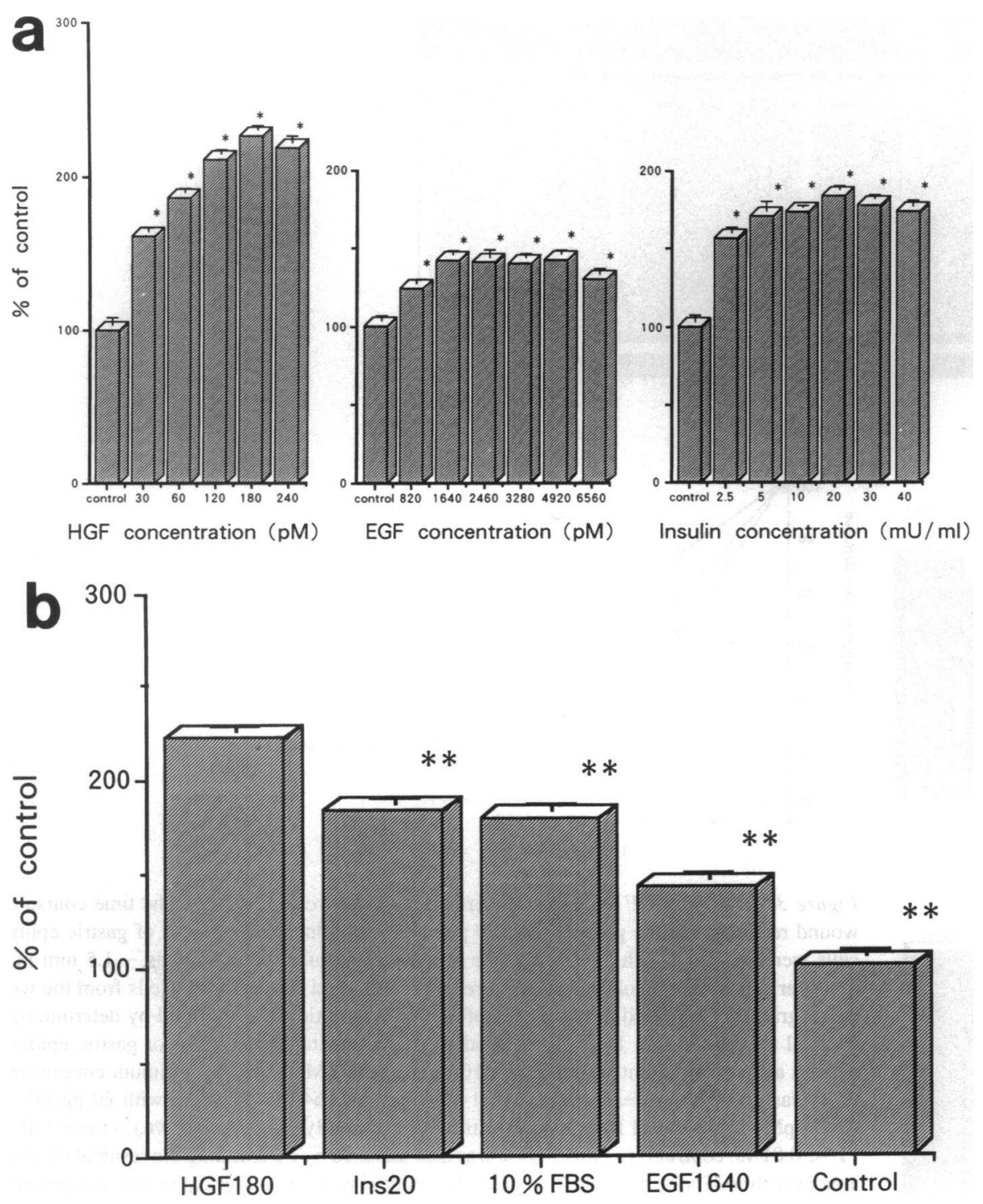

Figure 2. DNA synthesis by gastric epithelial cells cultured for $24 \mathrm{~h}$ with various agents, as assessed by $\left[{ }^{3} \mathrm{H}\right]$ thymidine incorporation. Every agent significantly stimulated DNA synthesis in a dose-dependent manner. These experiments were performed simultaneously using epithelial cells from a single source. The vertical axis shows a percentage of the control value converted from counts per minute. (a) HGF, EGF, and insulin all stimulated DNA synthesis in a dose-dependent manner. The maximal response was obtained with 180 pM HGF, 1640 pM EGF, and 20 $\mathrm{mU} / \mathrm{ml}$ insulin. The optimum HGF concentration was extremely low, being less than a ninth of that for EGF. ( $b$ ) Comparison of the maximum DNA synthesis induced by HGF, EGF, insulin, and $10 \%$ FBS indicated that the relative mitogenic potency was in the order of HGF $>$ insulin $>10 \%$ FBS $>$ EGF. $($ mean \pm SE, $* P$ $<0.01$ vs. control, $* * P<0.01$ vs. HGF.) at $4^{\circ} \mathrm{C}$ for $15 \mathrm{~min}$ and at room temperature for $15 \mathrm{~min}$, cleared in methyl benzoate for $30 \mathrm{~min}$ and then in xylene for $30 \mathrm{~min}$ consecutively, and finally embedded in paraffin. Sections $2-\mu \mathrm{m}$ thick were cut and deparaffinized with xylene, immersed in acetone, and incubated in methanol with $0.3 \%$ hydrogen peroxide for $30 \mathrm{~min}$ at room temperature to block endogenous peroxidase activity. Some samples were incubated with heparinase-1 $(0.5 \mathrm{U} / \mathrm{ml}$; Sigma Chemical Co. $)$ in phosphate-buffered saline (PBS) at $37^{\circ} \mathrm{C}$ for $30 \mathrm{~min}$. After rehydration with PBS, the sections were preincubated with $2 \%$ normal swine serum (NSS) in PBS, and then incubated for $2 \mathrm{~h}$ at room temperature with either a polyclonal antibody against human recombinant HGF or with control non-immunized rabbit serum diluted to $1: 2000$ with $2 \%$ NSS. Next, the sections were washed three times in PBS and incubated for $30 \mathrm{~min}$ with biotinylated anti-rabbit IgG (Nichirei, Tokyo, Japan) diluted to 1:200 with 2\% NSS. After washing three times in PBS, the sections were incubated for $30 \mathrm{~min}$ with avidin-biotin-peroxidase complex prepared using a Histofine ABC kit (Nichirei). Then the sections were washed in PBS, and incubated for $5 \mathrm{~min}$ in a solution containing $0.02 \%$ diaminobenzidine and $0.03 \%$ hydrogen peroxide in $0.1 \mathrm{M}$ Tris- $\mathrm{HCl}$ buffer ( $\mathrm{pH} 7.6)$. Nuclear counterstaining was performed with Mayer's hematoxylin.

\section{Statistical analysis}

Data are presented as mean \pm SE for $n$ determinations. Comparisons between two groups were made by a Student's $t$ test for grouped or paired data when appropriate; comparisons among several groups were made by analysis of variance, followed by Dunnett's test, when appropriate. In all analyses, statistical significance was attributed at a $95 \%$ or greater confidence level.

\section{Results}

Cell culture and identification. Cultured cells formed subconfluent monolayers at $48 \mathrm{~h}$ after inoculation and $93 \%$ of the cells in these monolayers had PAS-positive material in the cytoplasm (Fig. $1 a$ ). Three percent of the cells showed a strong reaction for succinic dehydrogenase activity, indicating that they were parietal cells, and $2 \%$ of the cells had granules positive for Bowie staining, indicating that they were chief cells. Transmission electron microscopy revealed that the majority of the cells contained electron-dense granules which are characteristic of mucous cells. These findings indicated that the cultures consisted mainly of mucous-producing cells (28). As mentioned earlier, these mucous-producing cells died after one month of culture and fibroblasts became predominant (Fig. $1 b$ ). The fibroblasts were stained with an anti-vimentin antibody and not 

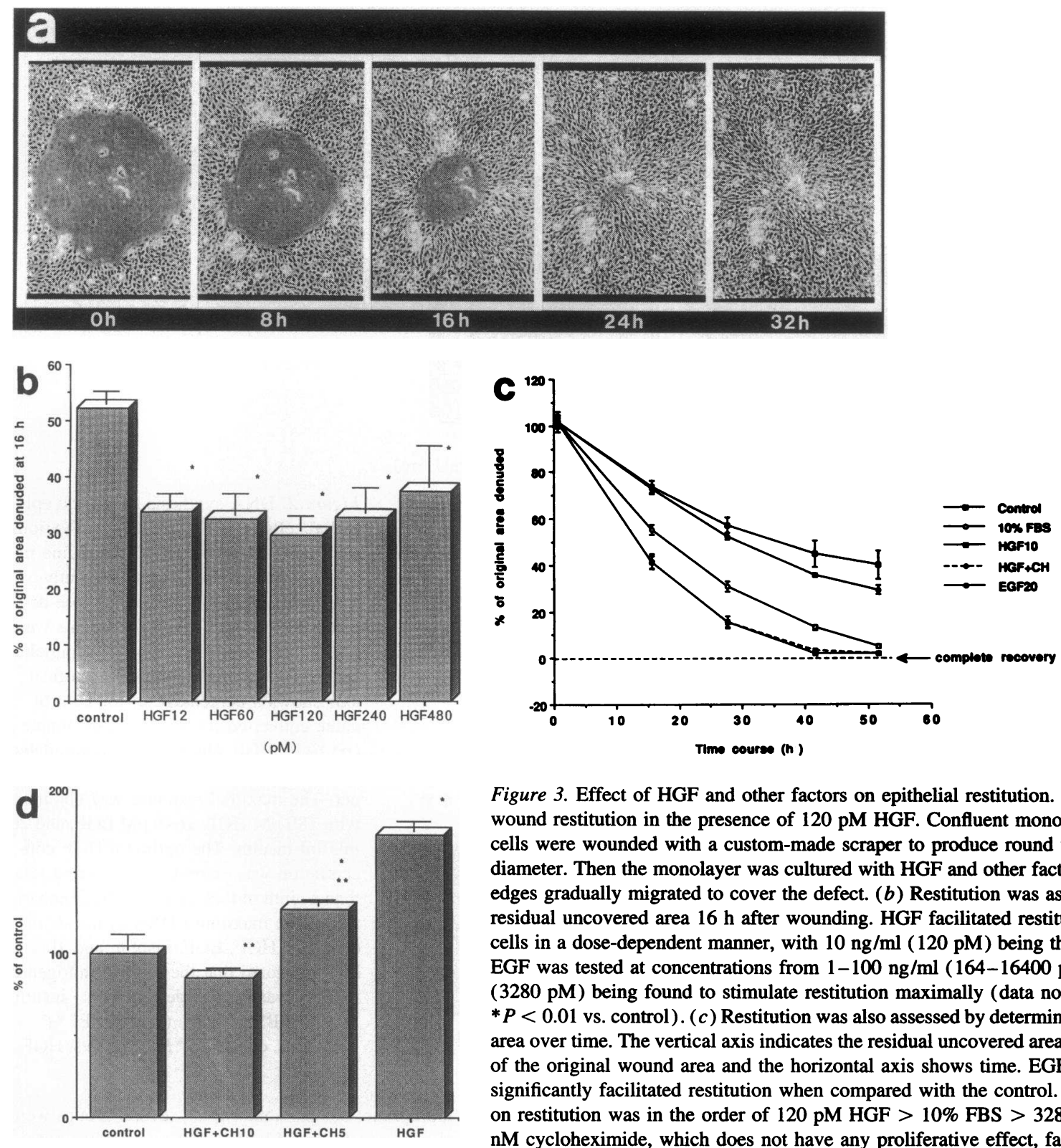

Figure 3. Effect of HGF and other factors on epithelial restitution. (a) The time course of wound restitution in the presence of 120 pM HGF. Confluent monolayers of gastric epithelial cells were wounded with a custom-made scraper to produce round wounds $\sim 1.5 \mathrm{~mm}$ in diameter. Then the monolayer was cultured with HGF and other factors. Cells from the wound edges gradually migrated to cover the defect. ( $b$ ) Restitution was assessed by determining the residual uncovered area $16 \mathrm{~h}$ after wounding. HGF facilitated restitution of gastric epithelial cells in a dose-dependent manner, with $10 \mathrm{ng} / \mathrm{ml}(120 \mathrm{pM})$ being the optimum concentration. EGF was tested at concentrations from 1-100 ng/ml (164-16400 pM), with $20 \mathrm{ng} / \mathrm{ml}$ $(3280 \mathrm{pM})$ being found to stimulate restitution maximally (data not shown). (mean $\pm \mathrm{SE}$, $* P<0.01$ vs. control). (c) Restitution was also assessed by determining the residual uncovered area over time. The vertical axis indicates the residual uncovered area expressed as a percentage of the original wound area and the horizontal axis shows time. EGF, 10\% FBS, and HGF significantly facilitated restitution when compared with the control. The potency of the effect on restitution was in the order of 120 pM HGF > 10\% FBS > 3280 pM EGF. HGF with 10 $\mathrm{nM}$ cycloheximide, which does not have any proliferative effect, facilitated restitution to the same extent as in its absence. Each plot represents the mean \pm SE. (HGF10, $10 \mathrm{ng} / \mathrm{ml}[120$

pM] HGF; $H G F+C H, 10 \mathrm{ng} / \mathrm{ml}$ [120 pM] HGF with $10 \mathrm{nM}$ cycloheximide; EGF20, $20 \mathrm{ng} / \mathrm{ml}$ [3280 pM] EGF.) (d) Cycloheximide suppressed DNA synthesis induced by 120 pM HGF in a dose-dependent manner and at the concentration of $10 \mathrm{nM}$, it completely blocked the DNA synthesis. ( $H G F, 120$ pM HGF; $C H$, cycloheximide [nM], mean \pm SE, ${ }^{*} P<0.01$ vs. control; ${ }^{* *} P<0.01$ vs. HGF.)

stained with an anti-cytokeratin antibody, whereas the epithelial cells were stained with the anti-cytokeratin antibody and not with the anti-vimentin antibody (data not shown). This result is in accordance with the fact that cytokeratin is an epithelialspecific protein and vimentin is a mesenchymal-specific protein that is normally expressed by fibroblasts.

Effect of HGF on gastric epithelial cell proliferation. HGF significantly stimulated DNA synthesis by gastric epithelial cells in a dose-dependent fashion, as we have reported previously (25). The dose-response profiles for EGF and insulin were also determined simultaneously. The maximal response was obtained with $15 \mathrm{ng} / \mathrm{ml}$ (180 pM) HGF, $10 \mathrm{ng} / \mathrm{ml}$ (1640 pM) EGF, and $20 \mathrm{mU} / \mathrm{ml}$ insulin (Fig. $2 a$ ). This optimum HGF concentration was extremely low, considering that the molecular weight of HGF is more than ten times greater than that of EGF. We simultaneously compared the maximal DNA synthesis of gastric epithelial cells stimulated by HGF, EGF, insulin, and $10 \%$ FBS, using cells from the same source to avoid variations due to differences in the background conditions. The maximal DNA synthesis induced by HGF was significantly higher than that induced by the other factors (HGF $>$ insulin $>10 \%$ FBS $>$ EGF) (Fig. $2 b$ ). These findings indicate that HGF is the most potent mitogen for gastric epithelial cells among those studied, as was also the case for hepatocytes in a previous study (17).

Effect of HGF and other factors on restitution. Confluent monolayers of gastric epithelial cells were wounded with a custom-made scraper that produced a round wound $\sim 1.5 \mathrm{~mm}$ 
in diameter, and then were cultured with HGF and other factors. Cells from the edges of the wound gradually migrated to cover the defect. Fig. $3 a$ shows the time course of wound restitution in the presence of $10 \mathrm{ng} / \mathrm{ml}$ HGF. EGF $(1-100 \mathrm{ng} / \mathrm{ml}), 10 \%$ FBS, and HGF ( $1-40 \mathrm{ng} / \mathrm{ml}$ ) all significantly facilitated restitution when compared with the control. EGF maximally stimulated restitution at a concentration of $20 \mathrm{ng} / \mathrm{ml}$ ( $3280 \mathrm{pM}$ ) (data not shown). Fig. $3 b$ shows the dose-response of the effect of HGF on the restitution of gastric epithelial cells at $16 \mathrm{~h}$ after wounding of the monolayers. It was found that $10 \mathrm{ng} / \mathrm{ml} \mathrm{(120}$ pM) was the optimum concentration. HGF showed by far the most potent promotion of restitution among the agents tested (Fig. $3 c$ ), and its effect was synergistic with that of EGF (data not shown). Addition of cycloheximide at a concentration (10 $\mathrm{nM}$ ) which completely blocked the induction of DNA synthesis by HGF (Fig. $3 d$ ) had no effect on the restitution process, suggesting that HGF stimulated restitution by facilitating migration alone without any effect on mitogenesis.

Binding assay. Fig. $4 a$ shows typical saturation curves for ${ }^{125} \mathrm{I}$-HGF binding to its receptor on cultured gastric epithelial cells. The specific binding of HGF was saturated at about 50 pM. We performed Scatchard analysis, plotting bound ${ }^{125} \mathrm{I}-$ $\mathrm{HGF} /$ free ${ }^{125} \mathrm{I}-\mathrm{HGF}$ as vertical axis and bound ${ }^{125} \mathrm{I}-\mathrm{HGF}$ as horizontal axis (32). To obtain regression, we used the least squares method. Scatchard analysis yielded a rectilinear plot, suggesting the presence of a single class of high-affinity binding sites (Fig. $4 b$ ). The Kd value and the number of HGF receptors calculated from the Scatchard plot was $32 \pm 19.7 \mathrm{pM}$ and $488 \pm 124$ sites/ gastric epithelial cell, respectively ( $95 \%$ confidence interval).

Expression of c-met $m R N A$. The reverse transcription polymerase chain reaction (RT-PCR) technique was initially used to detect the HGF specific receptor, c-met mRNA expression in primary cultures of gastric epithelial cells and gastric fibroblasts. Both types of cells yielded a single amplified band with an estimated size of 242 bp. Then, we performed Northern hybridization with the RT-PCR product as a probe. The expression of HGF specific receptor, c-met mRNA was clearly seen in the gastric epithelial cells, while little expression, if any, was seen in the gastric fibroblasts (Fig. 5).

Effect of fibroblast-conditioned medium on gastric epithelial cell proliferation. Conditioned medium obtained from the cultured fibroblasts stimulated the growth of gastric epithelial cells in a concentration-dependent fashion (25) and boiling of the conditioned medium eliminated this effect (data not shown). The proliferative effect of the conditioned medium was neutralized by an anti-HGF antibody in a dose-dependent manner (Fig. $6 a$ ), while it was not affected by normal chicken IgG (data not shown). In contrast, the proliferative effect of EGF was not influenced by this antibody (Fig. $6 \mathrm{~b}$ ). These results indicate that the proliferative effect of the conditioned medium was at least partly due to HGF produced by fibroblasts.

Effect of fibroblast-conditioned medium on gastric epithelial cell restitution. Conditioned medium obtained from cultured fibroblasts also facilitated the restitution of gastric epithelial cell monolayers (Fig. 7) and boiling of the conditioned medium eliminated this effect (data not shown). The stimulatory effect of the conditioned medium on restitution was also neutralized by the anti-HGF antibody (Fig. 7), while it was not affected by normal chicken IgG (data not shown). Addition of the antiHGF antibody alone at the dilution used in this studies did not have any effect on the restitution of gastric epithelial cells (data not shown). These results indicate that the stimulatory effect
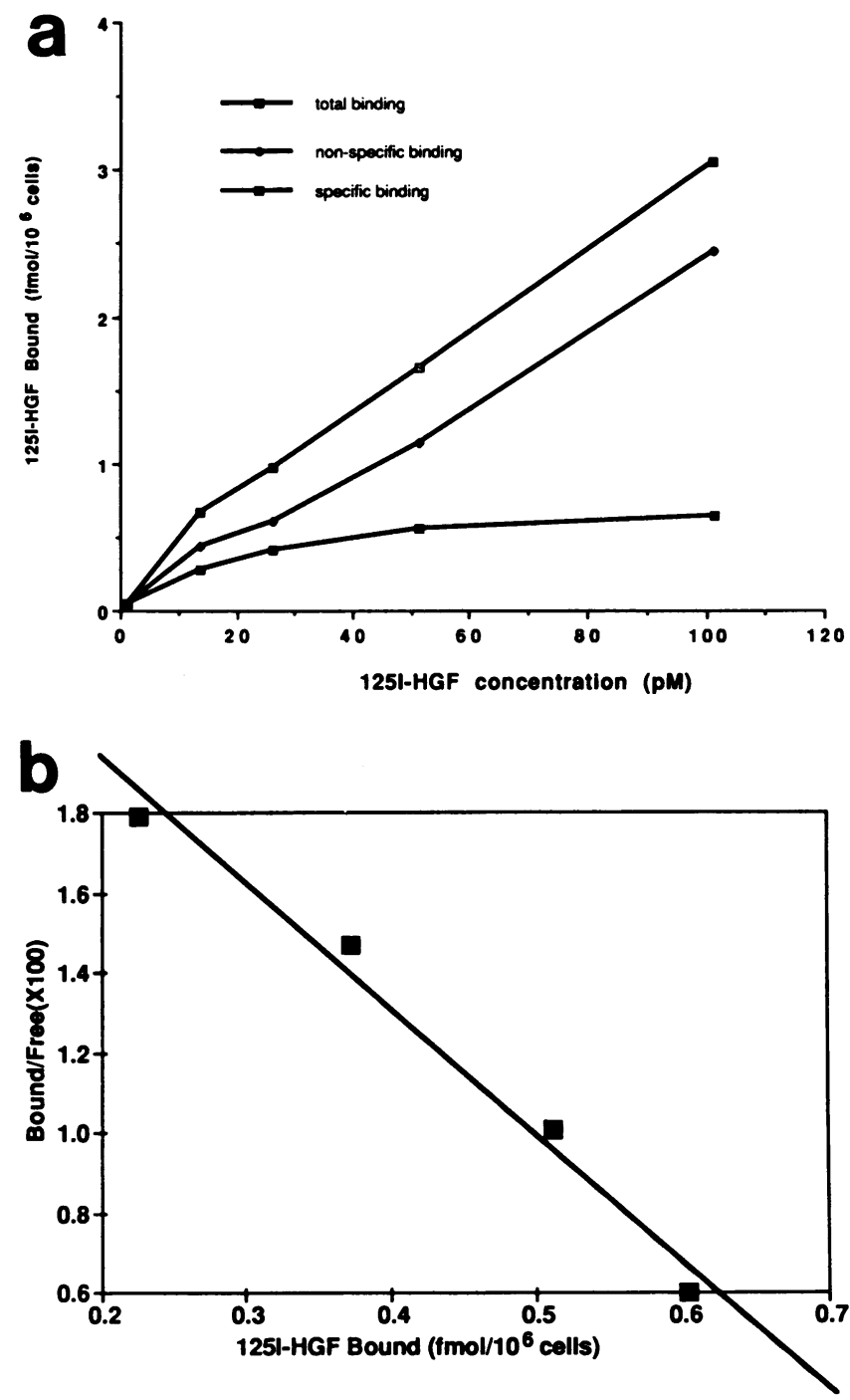

Figure 4. (a) Saturation curve for the binding of ${ }^{125}$ I-HGF to its receptor on cultured gastric epithelial cells. Sparse $\left(1.4 \times 10^{5}\right.$ cells $/$ well $)$ monolayers of rabbit gastric epithelial cells were incubated for $1 \mathrm{~h}$ at $10^{\circ} \mathrm{C}$ with ${ }^{125}$-labeled HGF alone or with $10 \mathrm{nM}$ unlabeled HGF. (b) Scatchard plot. We performed Scatchard analysis, plotting bound ${ }^{125}$ I-HGF/ free ${ }^{125}$ I-HGF as vertical axis and bound ${ }^{125}$ I-HGF as horizontal axis. To obtain a regression line, we used the least squares method. The $K_{\mathrm{d}}$ value was $32 \pm 19.7 \mathrm{pM}$. The number of HGF receptors was $488 \pm 124$ sites/cell ( $95 \%$ confidence interval).

of the conditioned medium on restitution was at least partly due to HGF produced by fibroblasts.

Expression of $H G F$ mRNA. Fig. 8 shows the expression of HGF mRNA by gastric epithelial cells and fibroblasts. Northern blot analysis clearly demonstrated the expression of HGF mRNA by gastric fibroblasts, but not by gastric epithelial cells.

HGF mRNA expression at the edges of gastric ulcers. We used the RT-PCR technique to detect HGF mRNA expression. We extracted total RNA from the biopsy samples of 16 patients. When the RT-PCR was performed, 14 out of 16 samples revealed a single band corresponding to a DNA fragment of the predicted size (539 bp), which suggested the production of HGF at the ulcer edges. Whereas, 9 out of 16 biopsies from normal gastric mucosa reveal a single band corresponding to 


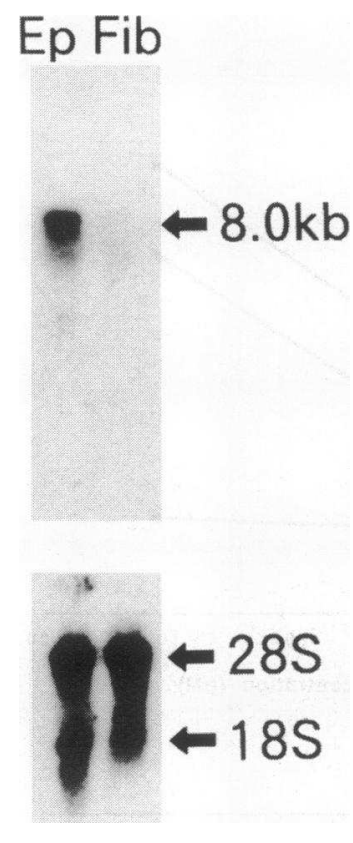

Figure 5. Expression of HGF specific receptor, c-met mRNA. The RT-PCR technique was initially used to detect $c$ met mRNA expression. RT-PCR was performed using a set of primers ( sense: $5^{\prime}{ }^{3905}$ GGT TGC TGA TTT TGG TCA TGC $^{3925} 3^{\prime}$; antisense: $5^{\prime 4126}$ TTC GGG TTG TAG GAG TCT TCT ${ }^{4146} 3^{\prime}$ ) and RNA from cultured gastric epithelial cells, which yielded a single amplified band with an estimated size of $242 \mathrm{bp}$. Then, Northern blot hybridization was done using the RT-PCR product as a probe to confirm that c-met mRNA was expressed by gastric epithelial cells, while little expression, if any, was seen in gastric fibroblasts.
HGF mRNA. The difference between ulcer edges and normal mucosa is significant $(P=0.02)$. Fig. 9 shows a representative demonstration of HGF mRNA expression in tissues from the edge of a gastric ulcer and from normal gastric mucosa. Since the PCR primers used corresponded to sequences in exon 8 and exon 13 between which there are introns, only the first strand cDNA of full length HGF would yield a PCR product of this size.

Distribution of HGF in human gastric ulcers and normal mucosa. We stained tissues obtained endoscopically from the edges of gastric ulcers or from normal gastric mucosa at a site sufficiently distant from any ulcers. The tissues were treated with heparinase in order to avoid the binding of HGF to heparin or heparan sulfate in the extracellular matrix, since HGF has a strong affinity to heparin (37).

Spindle-shaped cells located beneath the epithelial cells, probably fibroblasts from the ulcer edges, were clearly and strongly stained by the anti-HGF antibody, suggesting the presence of HGF protein in these cells (Fig. $10 a$ ). These cells were not stained by non-immunized rabbit serum (Fig. $10 \mathrm{~b}$ ), indicating that the staining was specific for HGF. In contrast, there was no positive staining of the tissues from normal gastric mucosa (Fig. $10 \mathrm{c}$ ). We stained three pairs of samples (ulcer edge and normal mucosa) from different patients and obtained the same results. These results indicates that HGF is localized at ulcer edges.

\section{Discussion}

Various growth factors have been recognized as important in the maintenance and repair of organs throughout the body (38, 39). In the stomach, the gastric epithelial cells are continuously renewed and damage to the epithelium induces the common diseases of gastritis and peptic ulcer. Several growth factors, such as TGF- $\alpha$ and bFGF, have been suggested to be involved in gastric mucosal repair. In the present study, we demonstrated that HGF had a strong proliferative effect on rabbit gastric epithelial cells in primary culture. The maximum DNA synthe-
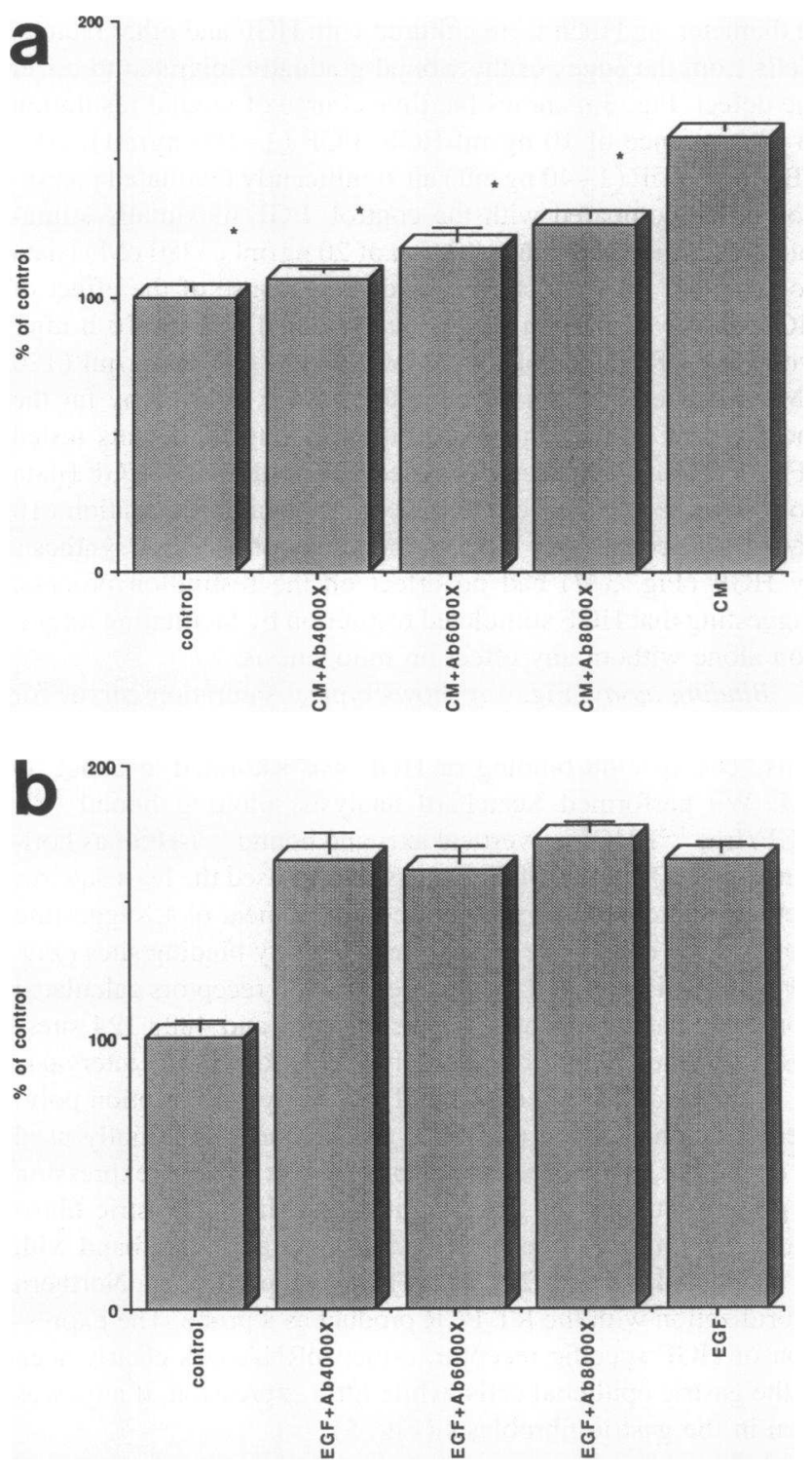

Figure 6. (a) Suppression of DNA synthesis induced by fibroblastconditioned medium in the presence of an anti-rabbit HGF antibody as assessed by $\left[{ }^{3} \mathrm{H}\right]$ thymidine incorporation. The conditioned medium (CM) was F-12 medium containing $0.1 \%$ BSA incubated with gastric fibroblasts at $37^{\circ} \mathrm{C}$ for $24 \mathrm{~h}$, which contained factors produced and secreted by the fibroblasts. The conditioned medium had a proliferative effect on gastric epithelial cells, which was neutralized by an anti-HGF antibody, suggesting that factor in the medium was HGF. The control was F-12 medium containing $0.1 \%$ BSA without being incubated with the fibroblasts. (mean $\pm \mathrm{SE},{ }^{*} P<0.01$ vs. conditioned medium alone. $\mathrm{CM}$, conditioned medium; $A b 4000 \mathrm{X}$, antibody at a dilution of 1:4000, etc.). ( $b$ ) EGF-induced DNA synthesis was not affected by the antirabbit HGF antibody, demonstrating that its neutralizing effect was specific to HGF (mean \pm SE).

sis induced was greater than that produced by insulin, EGF, or $10 \%$ FBS. The optimum HGF concentration producing this effect was also extremely low, considering the high molecular weight of this factor (more than ten times that of EGF). In this respect, HGF is the strongest mitogen for the gastric epithelium that has ever been reported and thus may have an important influence on the gastric mucosa. 


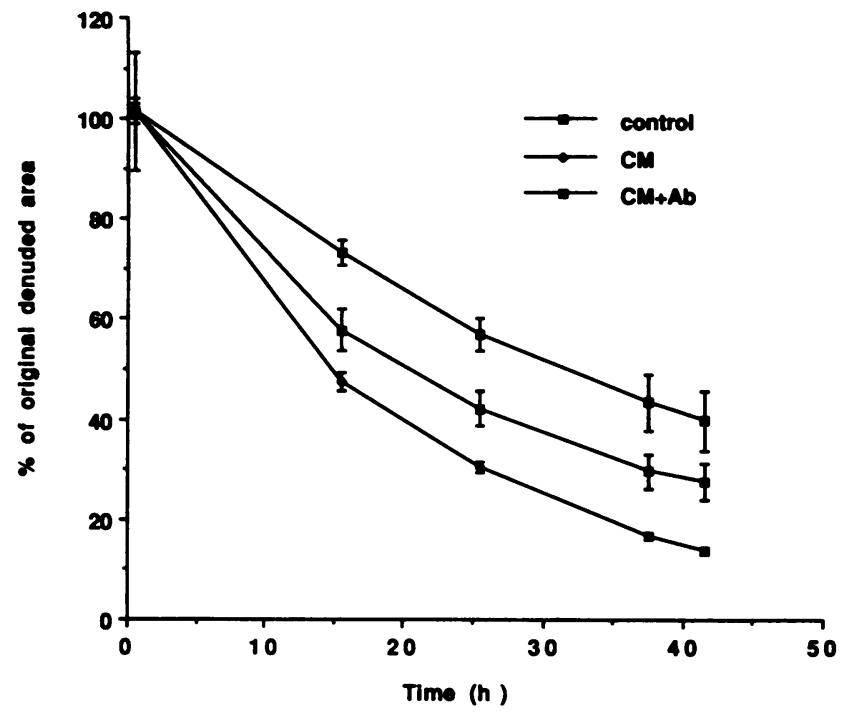

Figure 7. Effect of fibroblast-conditioned medium on gastric epithelial cell restitution. Conditioned medium also facilitated the restitution of gastric epithelial cell monolayers and this effect was suppressed by an anti-HGF antibody (dilution: 1:500), suggesting that HGF in the medium was involved in promoting restitution. Anti-HGF antibody alone at this dilution did not have any effect on restitution (data not shown). Each plot represents the mean \pm SE.

Although we demonstrated a proliferative effect of HGF on gastric epithelial cells, previous reports have suggested that cell migration is the principal force behind the early restitution of mucosal erosions in the gastrointestinal tract (40). However, there has been almost no investigation of the effect of various growth factors including HGF on either restitution or gastric epithelial cell migration. Nursat et al. reported that HGF facilitated the separation, spreading, and migration of T84 intestinal epithelial cells and thus enhanced wound healing, using the same in vitro round wound restitution model (41). It is interest-

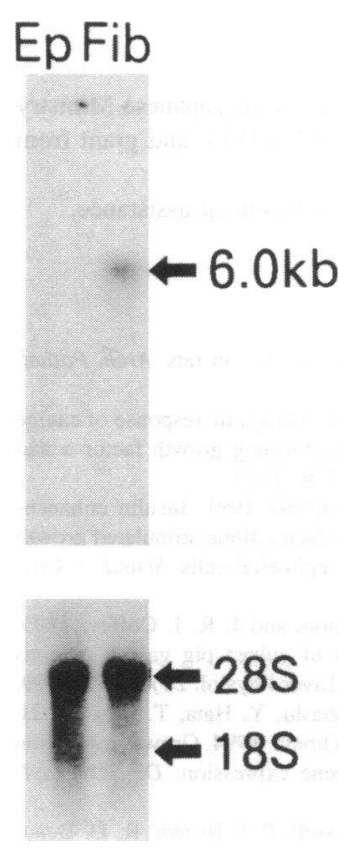
by gastric cells, as assessed by Northern blot hybridization. Northern blot hybridization was performed after extraction of poly (A) RNA from either gastric epithelial cells or gastric fibroblasts, using $1.4 \mathrm{~kb}$ HGF cDNA. Expression of HGF mRNA was seen in gastric fibroblasts, but not in gastric epithelial cells, indicating the production of HGF in the gastric fibroblasts, which was confirmed immunohistochemically (Fig. 9). ( $E p$, gastric epithelial cells; $F i b$, gastric fibroblasts.)

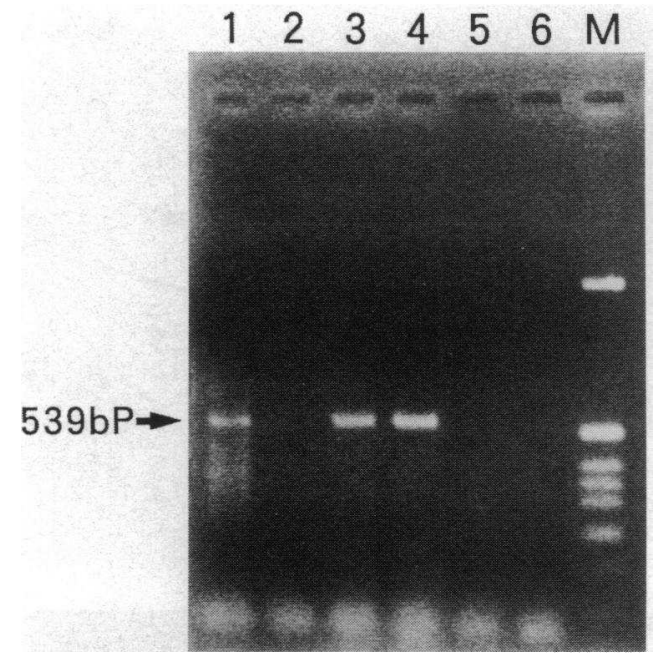

Figure 9. Representative demonstration of HGF mRNA expression in human tissue from the edge of a gastric ulcer. The 539-bp DNA fragment was produced by RT-PCR of total RNA the tissue using a pair of primers designed to amplify an HGF cDNA sequence. It was visualized with UV light following separation in $2 \%$ agarose gel and treatment with ethydium bromide solution. 14 out of 16 biopsy samples from gastric ulcer edges revealed HGF mRNA expression, while 9 out of 16 biopsies from normal gastric mucosa reveal HGF mRNA expressions. The difference between ulcer edges and normal mucosa is significant $(P=0.02)$. $1-3$ represent the biopsies from ulcer edges and 4-6 represent the biopsies from normal gastric mucosa.

ing that restitution is initiated by separation and spreading of the cells, according to their study. Since HGF is identical to scatter factor which is known to scatter various types of cells, their data seems acceptable. However, our observation of movie pictures revealed that the restitution of gastric epithelial cells induced by HGF occurred in the process called "sheet migration" where neighboring cells move together toward the wound center, instead of separation or spreading. This fact indicates that healing process of intestinal mucosa may be different from that of gastric mucosa. In any event, their result is in accordance with ours in the sense that HGF facilitated the restitution, although the concentration of HGF that they used was $200 \mathrm{ng} /$ $\mathrm{ml}$, which seems too high to be physiological considering that the HGF concentration eliciting maximal activity ranges from 5 to $10 \mathrm{ng} / \mathrm{ml}$ for many kinds of cells (17). Furthermore, our experiments showed consistently that the effect of HGF on gastric epithelial restitution was greater than that of EGF or $10 \%$ FBS and that the optimum HGF concentration for promoting restitution was quite low, as was also the case for proliferation. All these results suggest the importance of HGF in gastric mucosal repair.

A binding assay using radiolabeled HGF revealed specific binding to gastric epithelial cells, and expression of the HGF receptor (c-met) mRNA by gastric epithelial cells was also confirmed. These results were compatible with the immunohistochemical study of Prat et al., which demonstrated the presence of c-met protein in gastric epithelial cells (42). Accordingly, the proliferative effect of HGF on gastric epithelial cells appears to be a specific HGF receptor-mediated response.

To establish the physiological role of HGF in the gastric mucosa, the source of this factor needs to be identified. EGF is reported to be present in the circulation and the gastric juice 

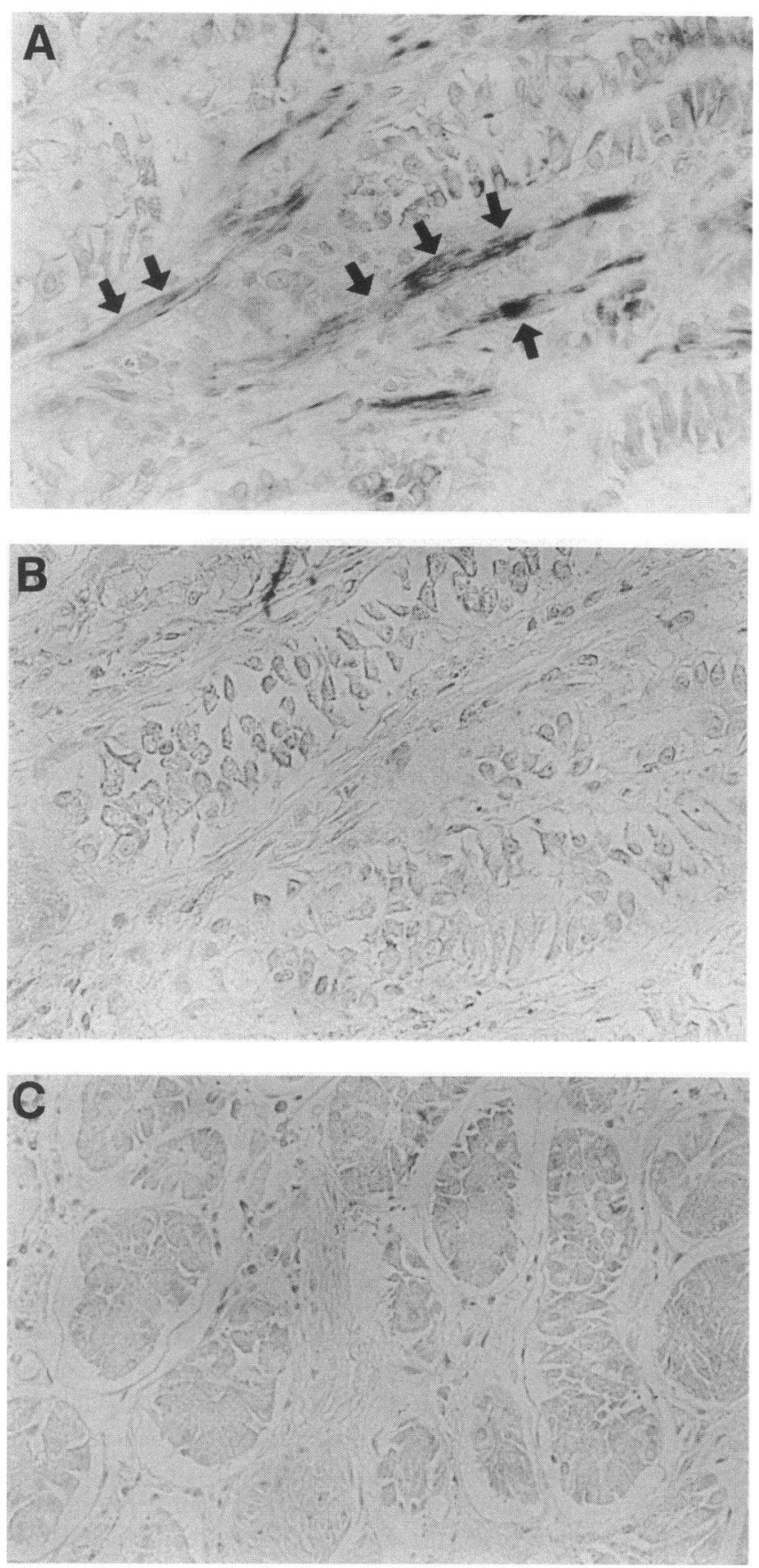

Figure 10. Immunohistochemical study of human gastric mucosa using anti-HGF antiserum. (a) Tissue obtained endoscopically from the edge of a gastric ulcer. The spindle-shaped cells, probably fibroblasts, under the epithelial cell layer are clearly and strongly stained by anti-HGF antiserum (arrow). (b) The same tissue as that shown in $a$ was also stained using non-immunized rabbit serum as a control. No detectable staining was seen, indicating that the staining with anti-HGF antiserum was specific for HGF. (c) Normal gastric mucosa obtained from the same patient at a site distant from the ulcer. No strong staining is seen with the anti-HGF antiserum.

(43). TGF- $\alpha$ may be secreted by gastric epithelial cells and appears to act in an autocrine or paracrine fashion, so it may be an autocrine or paracrine growth factor for gastric epithelial cells $(6,44)$. The source and the secretory mechanism of bFGF are not clearly understood, although the target of this factor has been suggested to be vascular endothelial cells (10). Since HGF is produced by various mesenchymal cells in other organs (22, 23,45 ), we postulated that gastric fibroblasts might also produce this factor. We have previously shown that conditioned medium obtained from cultured gastric fibroblasts stimulates the growth of gastric epithelial cells and that this action is additive with that of EGF or insulin, suggesting that it is not mediated by either of these factors. However, the factor in conditioned medium which stimulated proliferation was not defined in the previous study. The present study demonstrated that the effect of fibroblast-conditioned medium was neutralized by an anti-HGF antibody. In addition, gastric fibroblasts were shown to express HGF mRNA, while gastric epithelial cells did not. Furthermore, fibroblast-conditioned medium facilitated the restitution of gastric epithelial cells after the wounding of confluent monolayers. These findings confirm the production of HGF by gastric fibroblasts and support the role of HGF as a paracrine growth factor for gastric epithelial cells which is involved in "mesenchymal-epithelial interactions". In addition, we demonstrated the existence and production of HGF at the edges of human gastric ulcers by immunostaining with antiHGF antibody and the RT-PCR. It was found that HGF was mainly localized in the mesenchymal tissues, particularly in the fibroblasts. These findings support the role of HGF as a paracrine factor involved in gastric ulcer repair, as our in vitro studies also indicated. Although various authors have indicated that HGF functions in a paracrine manner, it has never been clearly demonstrated for a single organ that locally produced HGF can actually act on the neighboring epithelial cells. Therefore, this report provides the first actual demonstration of the paracrine role of HGF.

It is generally believed that gastric mucosal defects such as erosions or ulcers are first replaced by granulation tissue which is subsequently covered by epithelial cells (46). Since granulation tissue is mainly composed of fibroblasts, our results indicate that HGF may play an important role in the re-epithelialization process. Thus, it is possible that HGF might be a potential therapeutic agent for peptic ulcer disease.

\section{Acknowledgments}

This work was supported in part by a grant from the Japanese Ministry of Education, Science and Culture (Kaken 05670454), and grant from The Fugaku Trust for Medical Research.

We thank Naoko Sasaki for her excellent technical assistance.

\section{References}

1. Myhre, E. 1960. Regeneration of the fundic mucosa in rats. Arch. Pathol. 70:476-485.

2. Chen, M. C., A. T. Lee, and A. H. Soll. 1991. Mitogenic response of canine fundic epithelial cells in short-term culture to transforming growth factor $\alpha$ and insulin-like growth factor 1. J. Clin. Invest. 87:1716-1723.

3. Rutten, M. J., P. Harmon, and D. R. Campbell. 1991. Insulin enhances epidermal growth factor- and transforming growth factor alpha-stimulated growth in primary cultures of guinea pig gastric mucous epithelial cells. Scand. J. Gastroenterol. 26:965-973.

4. Rutten, M. J., P. J. Dempsey, T. E. Solomon, and J. R. J. Coffey. 1993. TGF- $\alpha$ is a potent mitogen for primary cultures of guinea pig gastric mucous epithelial cells. Am. J. Physiol. 265 (Gastrointest. Liver Physiol. 28):G361-G369.

5. Yoshiura, K., S. Ota, A. Terano, M. Takahashi, Y. Hata, T. Kawabe, H. Mutoh, H. Hiraishi, R. Nakata, K. Okano, and M. Omata. 1994. Growth regulation of rabbit gastric epithelial cells and protooncogene expression. Dig. Dis. Sci. 39:1454-1463.

6. Polk, W. H., Jr., P. J. Dempsey, W. E. Russell, P. I. Brown, R. D. Beau- 
champ, J. A. Barnard, and J. R. J. Coffey. 1992. Increased production of transforming growth factor $\alpha$ following acute gastric injury. Gastroenterology. 102:1467-1474.

7. Beauchamp, R. D., J. A. Barnard, C. M. MacCuthen, J. A. Cherner, and R. J. Coffey. 1989. Localization of transforming growth factor alpha and its receptor in gastric mucosal cells. Implications for a regulatory role in acid secretion and mucosal renewal. J. Clin. Invest. 83:1017-1023.

8. Folkman, J., S. Szabo, and P. Vattay. 1990. Effect of oral administration of bFGF on healing of chronic duodenal ulcers, gastric secretion and acute mucosal lesions in rats. Gastroenterology. 98:45.

9. Szabo, S., P. Vattay, and R. E. Morales. 1989. Orally administered FGF mutein: effect on healing of chronic duodenal ulcers in rats. Dig. Dis. Sci. 34:1323.

10. Folkman, J., S. Szabo, M. Stovroff, P. MacNeil, W. Li, and Y. Shing. 1991. Duodenal ulcer. Discovery of a new mechanism and development of angiogenic therapy that accelerates healing. Ann. Surg. 214:414-427.

11. Morris, G. P., and J. L. Wallace. 1981. The roles of ethanol and of acid in the production of gastric erosions in rats. Virchow's Arch. B. 38:23-28.

12. Wang, J. Y., and L. R. Johnson. 1989. Induction of gastric and duodenal mucosal ornithine decarboxylase during stress. Am. J. Physiol. 257 (Gastrointest. Liver Physiol. 20):G259-G265.

13. Rutten, M. J., and S. Ito. 1983. Morphology and electrophysiology of guinea pig gastric mucosal repair in vitro. Am. J. Physiol. 257 (Gastrointest. Liver Physiol. 7):G171-G183.

14. Silen, W. 1983. Gastric mucosal defence and repair. In Physiology of the Gastrointestinal Tract. Second edition. L. R. Johnson, editor. Raven Press, New York. 1055-1069.

15. Silen, W., and S. Ito. 1985. Mechanisms for rapid re-epithelialization of the gastric mucosal surface. Ann. Rev. Physiol. 47:217-229.

16. Yeomans, N. D., D. J. B. S. John, and W. G. Deboer. 1973. Regeneration of gastric mucosa after aspirin-induced injury to the rat. Am. J. Dig. Dis. 18:773780 .

17. Nakamura, T. 1991. Structure and function of hepatocyte growth factor. Prog. Growth Factor Res. 3:67-85.

18. Matsumoto, K., and T. Nakamura. 1992. Hepatocyte growth factor: Molecular structure, roles in liver regeneration, and other biological functions. Crit. Rev. Oncogenesis. 3:27-54.

19. Igawa, T., S. Kanda, and H. Kanetake. 1991. Hepatocyte growth factor is a potent mitogen for cultured rabbit renal tubular epithelial cells. Biochem. Biophys. Res. Commun. 174:831-838.

20. Matsumoto, K., H. Tajima, and T. Nakamura. 1991. Hepatocyte growth factor is a potent stimulator for human melanocytes. Biochem. Biophys. Res. Commun. 176:45-51

21. Matsumoto, K., K. Yoshikawa, and T. Nakamura. 1991. Marked stimulation of growth and motility of human keratinocytes by hepatocyte growth factor. Exp. Cell. Res. 196:114-120.

22. Kinoshita, T., K. Tashiro, and T. Nakamura. 1989. Marked increase of HGF mRNA in non-parenchymal liver cells of rats treated with hepatotoxins. Biochem. Biophys. Res. Commun. 165(3):1229-1234.

23. Noji, S., K. Tashiro, E. Koyama, T. Nohno, K. Ohyama, S. Taniguchi, and T. Nakamura. 1990. Expression of hepatocyte growth factor gene in endothelial and Kupffer cells of damaged rat liver, as revealed by in situ hybridization. Biochem. Biophys. Res. Commun. 173:42-47.

24. DiRenzo, M. F., R. P. Narsimhan, M. Olivero, S. Bretti, S. Giordano, E. Medico, P. Gaglia, P. Zara, and P. M. Comoglio. 1991. Expression of the Met/ HGF receptor in normal and neoplastic human tissues. Oncogene. 6:1997-2003.

25. Takahashi, M., S. Ota, A. Terano, K. Yoshiura, M. Matsumura, Y. Niwa, T. Kawabe, T. Nakamura, and M. Omata. 1993. Hepatocyte growth factor induces mitogenic reaction to the rabbit gastric epithelial cells in primary culture. Biochem. Biophys. Res. Commun. 191:528-534.

26. Nakamura, T., T. Nishizawa, M. Hagiya, T. Seki, M. Shimonishi, A Sugimura, K. Tashiro, and S. Shimizu. 1989. Molecular cloning and expression of human hepatocyte growth factor. Nature (Lond.). 342:440-443.
27. Zarnegar, R., S. Muga, R. Rahija, and G. Michalopoulos. 1990. Tissue distribution of hepatopoietin-A: a heparin-binding polypeptide growth factor for hepatocytes. Proc. Natl. Acad. Sci. USA. 87:1252-1256.

28. Ota, S., A. Terano, and H. Hiraishi. 1990. A monolayer culture of gastric mucous cells from adult rabbits. Gastroenterol. Jpn. 25:1-7.

29. Terano, A., K. J. Ivey, and J. Stachra. 1982. Cell culture of rat gastric fundic mucosa. Gastroenterology. 83:1280-1291.

30. Nachlas, M. M., K. C. Tsou, and E. D. Souda. 1957. Cytochemical demonstration of succinic dehydrogenase by the use of a new p-nitrophenyl substituted ditetrazole. J. Histochem. Cytochem. 15:420-436.

31. Bowie, D. J. 1935. A method for staining the pepsinogen granules of gastric glands. Anat. Rec. 64:357.

32. Higuchi, O., and T. Nakamura. 1991. Identification and change in the receptor for hepatocyte growth factor in rat liver after partial hepatectomy or induced hepatitis. Biochem. Biophys. Res. Commun. 176:599-607.

33. Chomczynski, P., and N. Sacchi. 1987. Single-step method of RNA isolation by acid guanidium thiocyanate-phenol-chloroform extraction. Anal. Biochem 162:156-159.

34. Tashiro, K., M. Hagiya, T. Nishizawa, T. Seki, M. Shimonishi, S. Shimizu, and T. Nakamura. 1990. Deduced primary structure of rat hepatocyte growth factor and expression of the mRNA in rat tissues. Proc. Natl. Acad. Sci. USA $87: 3200$

35. Tsao, M., H. Zhu, A. Giaid, J. Viallet, T. Nakamura, and M. Park. 1993 Hepatocyte growth factor/scatter factor is an autocrine factor for human normal bronchial epithelial and lung carcimoma. Cell Growth \& Differ. 4:571-579.

36. Sato, Y., K. Mukai, S. Watanabe, M. Goto, and Y. Shimosato. 1986. The AMeX method: a simplified technique of tissue processing and paraffin embedding with improved preservation of antigens for immunostaining. Am. J. Pathol. 125:431-435.

37. Yoshinaga, Y., Y. Matsuno, S. Fujita, T. Nakamura, M. Kikuchi, Y Shimosato, and S. Hirohashi. 1993. Immunohistochemical detection of hepatocyte growth factor/scatter factor in human cancerous and inflammatory lesions of various organs. Jpn. J. Cancer Res. 84:1150-1158.

38. Sporn, M. B., and A. B. Roberts. 1993. A major advance in the use of growth factors to enhance wound healing. J. Clin. Invest. 92:2565-2566.

39. Lynch, S. E., R. B. Colvin, and H. N. Antoniades. 1989. Growth factors in wound healing. J. Clin. Invest. 84:640-646.

40. McCormack, S., A., M. J. Viar. and L. R. Johnson. 1992. Migration of IEC-6 cells: a model for mucosal healing. Am. J. Physiol. 263 (Gastrointest. Liver Physiol. 26):G426-G435.

41. Nursat, A., A. C. Parkos, E. A. Bacarra, J. P. Godowski, C. Delp-Archer, M. E. Rosen, and L. J. Madara. 1994. Hepatocyte growth factor/scatter factor effects on epithelia. Regulation of intercellular junction on transformed and nontransformed cell lines, basolateral polarization of c-met receptor in transformed and natural intestinal epithelia, and induction of rapid wound repair in a transformed model epithelium. J. Clin. Invest. 93:2056-2065.

42. Prat, M., R. P. Narsimhan, T. Crepaldi, M. R. Nicotra, P. G. Natali, and P. M. Comoglio. 1991. The recepor encoded by the human c-MET oncogene is expressed in hepatocytes, epithelial cells and solid tumors. Int. J. Cancer. 49:323328

43. Konturek, J. W., W. Bielanski, S. J. Konturek, J. Bogdal, and J. Oleksy 1989. Distribution and release of epidermal growth factor in man. Gut. 30:11941200.

44. Chen, M. C., A. T. Lee, W. E. Karmes, D. Avedian, M. Martin, J. M. Sorvillo, and A. H. Soll. 1993. Paracrine control of gastric epithelial cell growth in culture by transforming growth factor- $\alpha$. Am. J. Physiol. 264 (Gastrointest. Liver Physiol. 27):G390-G396.

45. Yanagita, K., M. Nagaike, H. Ishibashi, Y. Niho, K. Matsumoto, and T Nakamura. 1992. Lung may have an endocrine function producing hepatocyte growth factor in response to injury of distal organ. Biochem. Biophys. Res. Commun. 182:802-809.

46. Szabo, S. 1991. Mechanism of gastric mucosal injury and protection. J. Clin. Gastroenterol. 13 Suppl 2:S21-34. 